\title{
Physicochemical properties of Sorghum malt and Bambara Groundnut Based extrudates
}

\author{
G. JIDDERE ${ }^{1}$ and K. B. FILLI ${ }^{1,2 *}$ \\ ${ }^{1}$ Department of Food Science \& Technology Modibbo Adama University of Technology Yola, PMB 2076 Yola, Nigeria \\ ${ }^{2}$ SP Food and Bioscience Food and Bioscience Box 5401, 40229 Gothenburg, Sweden
}

Extrusion cooking has been used as an important technique for the manufacture and modification of wide variety of food products such as expanded snack foods, ready-to-eat cereals which are made from foods with high starch and protein. Although starchy foods are the predominant structure forming agents, their utilization as food has been limited by their poor protein quality and quantity. The supplementation with legumes improves the essential amino acid content of the food. Bambara groundnut has balanced amino acid content and can supplement the quality of amino acids in sorghum. Starch from sorghum flour has been found to be resistant to extrusion. This makes the modification of functional properties very difficult. Malting of the sorghum has been adopted for the modification of the starch quality. The nutrient and functional properties of food play major role in their application and use as food. This work has studied the effect of feed moisture (20\%, 25\%, and 30\%) and barrel temperature $\left(100^{\circ} \mathrm{C}, 110^{\circ} \mathrm{C}\right.$ and $\left.130^{\circ} \mathrm{C}\right)$ on the chemical composition and functional properties of sorghum malt and Bambara groundnut blends. From the results of the analyses, protein content varied from $11.07 \%$ to $11.75 \%$. Increase in barrel temperature decreased the protein content while feed moisture increase favoured the retention of proteins. The expansion index (EI), water absorption index (WAI) and effect of quantity of water on swell volume (EQWSV) varied from 1.88 to 3.88, 570\% to $660 \%$ and 13.7 seconds to 33.4 seconds respectively. These properties are negatively affected by increase in feed moisture but they improve with increases in barrel temperature. The values for water solubility index (WSI), bulk density and Wettability ranged from $2.2 \%$ to $8.4 \%, 0.2 \mathrm{~g} / \mathrm{cm}^{3}$ to $0.7 \mathrm{~g} / \mathrm{cm}^{3}$ and 14.3 seconds to 37.3 seconds respectively. The increase in feed moisture has positive influence on these parameters while temperature increased affected them negatively.

Keywords: Expansion index, bulk density, feed moisture, barrel temperature, sorghum malt, Bambara groundnut, protein content.

\section{Introduction}

Globally, the snack food industry is fetching up bigger and more imperative every day. In the last ten years, revolution in the way of living and eating habits have resulted in an ongoing increased demand for snack foods and these snacks can supply a better dietary intake of essential amino acids and other food nutrients for developing countries. Food products are complex multi-component systems that may contain mixtures of protein and polysaccharides, either as inherent components of foods such as maize, meat, fish, fruit and vegetables or added by the manufacturer as thickeners, stabilizers, emulsifiers or gelling agents (Razzaq, 2012).

The Functional property of a food refers to the property characterizing the structure, quality, nutritional value and or acceptability of the food product. A foods functional property is determined by physical, chemical and or organoleptic properties of the food, these may include solubility, absorption, water retention, frothing ability, elasticity, and absorptive capacity for fats and foreign particles (Chessari and Sallahewa, 2012).

In Africa, the major food staples have been cereal grains for many centuries. Although, the cereals have been servicing the need of the people over these years, it has been found that the cereal grains are poor in the protein quality and quantity most especially in the amino acid Lysine and Tryptophan. These are referred to as limiting amino acids in cereals. The low protein value has limited the sole utilization of cereal grains for food. The co-consumption of cereals with other food products such as animal foods, vegetable

*Corresponding author, E-mail: kbfilli@yahoo.com 
and legumes become one of the best alternatives for cereal complementation in term of the protein requirements. Extrusion alters the nature of many food constituents, including starches, proteins, by changing their physical, chemical and nutritional properties. The High temperature short time extrusion cooking technology has limitless application in processing of cereals based products. Extrusion cooking is a popular process of preparing snacks and ready to eat foods (Filli et al., 2012).Breakfast foods and snacks should have and expanded and a crispy texture. During extrusion-cooking of biopolymers, the passing of visco-elastic material through a die causes a sudden pressure drop with a given vapourization, resulting in and expanded and porous structure. Both elastic swelling and bubble growth effects contribute to the resulting expansion. These characteristics strongly depend on moisture content and extrusion temperature (De Philli et al., 2004). This work has attempted to study the effect of feed moisture and barrel temperature on the chemical composition and functional properties of sorghum malt and Bambara groundnut based extrudates.

\section{Materials and Methods}

The Chakalari local white (Sorghum bicolor) and improved Cream coloured (AS 17) Bambara groundnut (Vignasubterranea) was obtained from Ganye Main Market and the variety identified by Adamawa Agricultural Development Program (AADP) Yola Adamawa State Nigeria.

\section{Malting of sorghum}

The malting process was carried out as described by Mosha et al., (1997). The sorghum grain was locally aspirated and sorted to remove all foreign materials, broken and poorly developed seeds. The grains were then washed several times in potable water to remove dirt and adhering dust particles. The grains were soaked in potable water for $24 \mathrm{hrs}$. With the soak water changed every $8 \mathrm{hrs}$. The soaked grains were then drained and spread on a cleaned jut sack and allowed to germinate for three days. Cleaned water is intermittently sprinkled on the germinating grains at $12 \mathrm{hrs}$ interval throughout the germination period. After the three days period, the germination was arrested by drying in the sun for about $6 \mathrm{hrs}$ and the rootlets were removed by brushing followed by aspiration.

\section{Determination of germinating capacity of sorghum}

The modified method of Iwouno and Ojukwu (2012) was used. About 200 sorghum kernels were steeped for 24 hrs in $200 \mathrm{ml}$ fresh water at room temperature. The steep liquor was strained off and the grains were spread on moistened cotton wool and allowed to germinate for 2 days. The germinated grains were separated and counted. The Germinating capacity in percentage was found by:

$\%$ Germination capacity $=(200-\mathrm{n}) / 2 \times 100$

Where, $\mathrm{n}=$ number of ungerminated seeds

\section{Diastatic power determination}

About $3 \mathrm{~g}$ of the malt grits was weight out and extracted with $27.5 \mathrm{~cm}^{3}$ of distilled water and $2.5 \mathrm{~cm}^{3}$ of $0.1 \mathrm{~N} \mathrm{NH}_{4} \mathrm{OH}$ solution, the extract was not filtered but allowed to settle. $3 \mathrm{ml}$ aliquot of the supernatant liquid was removed using pipette into $100 \mathrm{ml}$ of $2 \%$ buffered starch solution kept at a temperature of $25^{\circ} \mathrm{C}$ in a $200 \mathrm{ml}$ flask. The flask was shook and allowed for $1 \mathrm{hr}$ The reaction was inhibited by the addition of $0.1 \mathrm{~N} \mathrm{NaOH}$ and the volume made up to $200 \mathrm{ml}$ at $20^{\circ} \mathrm{C}$ with distilled water. $5 \mathrm{ml}$ of mixed Fehling's solution was pipette into a $15 \mathrm{ml}$ narrow-necked boiling flask the content was mixed and was boiled with moderate heat for 2 min. It was titrated with the $2 \%$ buffered starch solution while heating until the blue colour of Fehling's solution was bleached. Three drops of Methylene blue indicator were added and the titration completed. The end point was indicated by the decolourization of the Methylene blue indicator to red (Iwouno and Ojukwu 2012). The Diastatic power (D.P) expressed in degree I.O.B was calculated from the expression:

\section{Diastatic power $=(2000-200) /(\mathrm{XY} \times \mathrm{SX})$}

Where,

$\mathrm{X}=$ number of $\mathrm{ml}$ of malt extract used to digest starch

$\mathrm{Y}=$ number of $\mathrm{ml}$ of converted starch to reduce $5 \mathrm{ml}$ of fehlings solution

$\mathrm{S}=\quad$ titre of starch blank.

\section{Determination of blank titre for starch}

The undiluted $2 \%$ starch solution was titrated against a mixture of $1 \mathrm{ml}$ of mixed Fehling's solution A and B, using the above described technique. The titre was taken as $\mathrm{S}$. The correction to be subtracted from the probable diastatic power of the malt is $200 / \mathrm{SX}$, where $\mathrm{X}$ is the number of $\mathrm{ml}$ of malt extract for the conversion. The blank is usually neglected if it is less than $3 \%$ of the measured diastatic power of the malt.

\section{Flour production from sorghum malt and bambara groundnut}

The sorghum malt and bambara groundnut grains were first manually aspirated to remove light contaminating materials. It was sorted to remove chaff, stones, rotten seeds and other heavy materials, and then washed in clean potable water 
until the washed water was no longer dirty. The grains were later dried in the sun for about 4 hrs with occasional turning during drying. It was then ground in a locally fabricated Attrition Mill and sieved through a $500 \mu \mathrm{m}$ sieve size. The flour was then packed in a low density polyethylene bag and stored at room temperature before Extrusion (Filli et al., 2012).

\section{Experimental design}

A two- factor three levels full factorial design was adopted for the study on effect of feed moisture and barrel temperature on the essential amino of extrudates from sorghum malt and bambara groundnut extrudates. The experimental design is given on Table 1.

Table 1. Independent variables and levels for full factorial design

\begin{tabular}{l|l|l|l|l}
\hline \multicolumn{2}{c}{ Level of variations } \\
\hline Independent variables & Symbols & 1 & 2 & 3 \\
\hline Feed moisture $(\%)$ & $\mathrm{X}_{1}$ & 20 & 25 & 30 \\
Barrel temperature $\left({ }^{\circ} \mathrm{C}\right)$ & $\mathrm{X}_{2}$ & 100 & 120 & 130 \\
\hline
\end{tabular}

The outline of the experimental layout with the coded and natural values is presented in Table 2 .

Experiments were carried out in triplicates and in a randomized order. ANOVA was adopted to determine the statistical level of significance of each sample and least significant difference for the separation of means.

Table 2. Experimental layout with the coded and natural values

\begin{tabular}{lcccc}
\hline \multicolumn{2}{c}{ Design point } & \multicolumn{2}{c}{ Independent variables in coded form } & \multicolumn{2}{c}{ Independent } \\
& $\mathrm{X}_{1}$ & $\mathrm{X}_{2}$ & $\mathrm{X}_{1}(\%)$ & $\mathrm{X}_{2}\left({ }^{\circ} \mathrm{C}\right)$ \\
\hline 1 & 1 & 1 & 20 & 100 \\
2 & 1 & 2 & 20 & 120 \\
3 & 1 & 3 & 20 & 130 \\
4 & 2 & 1 & 25 & 100 \\
5 & 2 & 2 & 25 & 120 \\
6 & 2 & 3 & 25 & 130 \\
7 & 3 & 1 & 30 & 100 \\
8 & 3 & 2 & 30 & 120 \\
9 & 3 & 3 & 30 & 130 \\
\hline
\end{tabular}

$\mathrm{X}_{1}=$ Feed Moisture, $\mathrm{X}_{2}=$ Barrel Temperature

\section{Conditioning and extrusion}

A calculated quantity of water was added to the fixed ratio of 70: 30 feed formulation (70\% sorghum malt and 30\% bambara groundnut) based on the desired feed moisture. It was thoroughly mixed using Horbart mixer model number A 200 for $10 \mathrm{~min}$ which ensured there were no lumps formed in the formulation. The conditioned blends were then packed in polythene bags and kept at room temperature for four hours before extrusion. The extrusion was carried out using SLG 65 twin screw co-rotating intermeshed extruder (Jinan Saibainu technology dev. Co. Ltd China). The compression level of the screw was 2:1 and length to diameter (L/D) ratio of 20:1. The extruder had three thermocouple heating zones and $3 \mathrm{~mm}$ die hole. It was equipped with a feeding hopper attached with a horizontal feeder which supplied the feed at $0.04 \mathrm{~kg} / \mathrm{s}$. A cutting knife with a variable speed was also attached to the die head. The formulations were extruded at $100^{\circ} \mathrm{C}, 120^{\circ} \mathrm{C}$ and $130^{\circ} \mathrm{C}$ and feed moisture contents of 20, 25 and $30 \%$ respectively. The extrudates were cooled, dried and stored in a polythene bag before further analysis. A total of nine extrusions were run in accordance with the experimental design.

\section{Determination of the moisture content}

Moisture content was determined by the AOAC, (1984) method. About $5 \mathrm{~g}$ of the ground extrudate was weight into cleaned, dried and pre-weight crucible. The cover was removed and the dish placed in a preheated oven for exactly $3 \mathrm{hrs}$ at $105^{\circ} \mathrm{C}$. The lid was replaced and the dish allowed to becooled in a desiccator for at least $1 \mathrm{hr}$ to room temperature. The dish was reweighed to $0.001 \mathrm{~g}$. The moisture content percentage of the samples was determined by the expression 
given below. The average value of three determinations was recorded:

$\%$ Moisture $=(W-w) / W \times 100$

Where,

$\mathrm{W}=$ Initial weight of sample before drying

$\mathrm{W}=$ Weight of sample after drying

\section{Crude fat determination}

Crude fat determination was determined by Soxhlet method as described by AOAC, (1984). Two grams of the extruded sample was weight and placed in an extraction thimble, the Soxhlet apparatus was set up. It was refluxed for $4 \mathrm{hrs}$ using hexane. After the extraction, the flask containing the 0il was dried to a constant weight at $105^{\circ} \mathrm{C}$ in an oven. Then it was cooled and weight.

$\%$ Oil $=(X-Y) / W \times 100$

Where,

$\mathrm{X}=$ Weight of flask with extracted oil

$\mathrm{Y}=$ Weight of empty flask

$\mathrm{W}=$ Weight of sample

\section{Crude protein determination}

The protein content was determined by Kjeldahl method as described by AOAC, (1984). About $0.5 \mathrm{~g}$ of the ground sample was digested with $25 \mathrm{ml}$ Concentrated Sulphuric acidin the presence of Kjehltabs (digestion catalyst: $\mathrm{CuSO}_{4}$, $\mathrm{Na}_{2} \mathrm{SO}_{4} \mathrm{SeO}$ ). The digest was neutralized with $50 \%$ sodium hydroxide solution and distilled into $2 \%$ screened Boric acid indicator then Titrated with $0.05 \mathrm{~N}$ Hydrochloric acid. The $\%$ crude protein was calculated as shown:

$\%$ Crude protein $=\frac{\text { Normality of acid used } \times \text { Vol.of acid used } \times 6.25 \times 14}{\text { Weight }} \times 100$ $6.25=$ nitrogen conversion factor

$14=$ molar weight of nitrogen

\section{Ash determination}

Ash content was determined by combusting $1 \mathrm{~g}$ of the extruded samples in a muffle furnace at $550^{\circ} \mathrm{C}$ for $4 \mathrm{hrs}$ in a crucible according to AOAC, (1984). Then the crucibles were cooled in a desiccator to room temperature before it was weight.

$\%$ Ash $=\frac{\text { Weight of crucible containing ash-weight of empty crucible }}{\text { Weight of sample }} \times 100$

\section{Total carbohydrate determination}

The carbohydrate content was estimated by subtracting the sum of percentage of moisture, fat, protein and ash contents 58 from 100\% according to Egan et al., (1981).

\section{Water absorption index/ water solubility index}

Water absorption index (WAI) and water soluble index (WSI) were determined using the method described by Filli et al., (2012). The ground extrudate were suspended in water at temperature of $30^{\circ} \mathrm{C}$ for $30 \mathrm{~min}$; it was stirred gently during this period and centrifuged at $3000 \mathrm{rpm}$ for $15 \mathrm{~min}$. The supernatant was decanted into an evaporating dish of known weight. The supernatant was filtered through a $500 \mu \mathrm{m}$ pore size filter paper into a pre-weight evaporating dish. It was then dried in a hot air oven at $105^{\circ} \mathrm{C}$ to constant weight. The difference in the weight of evaporating dish to the initial weight gives the water soluble index. While the WAI was considered as weight of the gel obtained after removal of the supernatant through the strainer (poor size $500 \mu \mathrm{m}$ ) per unit weight of original dry solids. The determinations were made in triplicates.

$\% W A I=\frac{\text { Water retained in the extrudate af ter decanting }}{\text { Weight of dry sample }} \times 100$

Bulk density

Bulk density was calculated as described by Filli et al., (2010). 10 randomly selected ungrounded extrudates were taken; the length, mass and diameter of each of the selected extrudates were measured using vernier calipers. The bulk density was calculated as shown below. The samples were randomly selected and replicated 10 times and the average result values taken.

Densty $(\rho)=\frac{4 \times \text { Mass of extrudate }}{\pi \times(\text { diameter of extrudate })^{2} \times \text { lenght }} \times 100$

\section{Expansion ratio}

Expansion ratio was carried out as described by Filli et al., (2012). The Diameter of the extrudateswas determined after cooling at 3 different points on the sample using vernier calipers. 10 samples were randomly selected extrudates were assessed for each of the extruded samples and the result averaged. Expansion ratio was expressed as the diameter of the extrudate to the diameter of the die.

$\%$ Expansion index $=\frac{\text { Average extrudate diameter }}{\text { Diameter of the die }} \times 100$

\section{Wettability}

Wettability was determined as described by Filli et al., (2012) one gram of each sample was placed in a $25 \mathrm{ml}$ graduated cylinder with a diameter of $1 \mathrm{~cm}$. a finger was placed over the open end and the cylinder inverted and clamped at a height of $10 \mathrm{~cm}$ from the surface of $600 \mathrm{ml}$ beaker containing $500 \mathrm{ml}$ distilled water. The finger was removed to allow the material to be dumped, and the time required for the sample to become completely wet was 
recorded. Triplicate measurements were made and the average result taken.

\section{Effect of quantity of water on specific volume (EQWSV)}

The EQSWV was determined using the method of Filli et al., (2012). $1 \mathrm{~g}$ of the ground extrudate was put into 10 test tubes of $20 \mathrm{ml}$ each. $1,2,3, \ldots \ldots . .9,10 \mathrm{ml}$ of distilled water was added to each of the test tubes. The test which recorded the highest expansion is taken as its EQSWV.

\section{Statistical analysis}

A two-way ANOVA of the results were carried out using Statistical Package for the Social Sciences (SPSS, 1998) for windows Illinois, USA). Means were separated using Duncan Multiple Range Test.

\section{Results and Discussion}

\section{Proximate composition of extruded blends}

The values for the proximate composition of the extrudates are given on Table 3 . The values of carbohydrate ranged from $71.04 \%$ representing the sample M0T0 to $82.0 \%$ representing the sample. It was observed that carbohydrates content increased with increase in temperature. This increase is a common phenomenon in extrusion process because of reduction in water content. The values for protein ranged from 11.0 to $12.5 \%$ for the samples M2T3; M3T3 and M0T0 respectively. The product with the highest protein content was the unextruded sample M0T0 $12.5 \%$, indicating that was a marginal loss of protein during extrusion process possibly through maillard reaction. The result indicated a significant difference at $p \geq 0.01$ for extruded samples and unextruded sample. There was however no significant difference among some of the extruded samples at $\mathrm{p} \geq 0.01$. The process conditions used in extrusion cooking - high barrel temperatures and low feed moistures are known to favour the Maillard reaction this is evident for the marginal lower contents of protein for sample extruded at $20 \%$ moisture. In the extrusion cooking of a cereal mixture, the loss of available lysine ranged from $32 \%$ to $80 \%$ at $170{ }^{\circ} \mathrm{C}$ mass temperature, $10-14 \%$ feed moisture and 60rpm screw speed (Beaufrand et al., 1978). There was a substantial loss (32\%) of available lysine without addition of sugars in the cereal mixture, which might be the result of hydrolysis of starch. Free sugars might be produced from starch hydrolysis during extrusion to react with lysine and other amino acids with free terminal amines. Starch and dietary fibre fragments, along with sucrose hydrolysis products, are available for Maillard reaction. Digestibility test was not carried out for this work; however there are reports on the protein digestibility value of extrudatesof being higher than nonextruded products Singh et al., 2007. The possible cause might be the denaturation of proteins and inactivation of antinutritional factors that impair digestion. The nutritional value in vegetable protein is usually enhanced by mild extrusion cooking conditions, owing to an increase in digestibility (Srihara\& Alexander, 1984; Hakansson et al., 1987; Colonna et al., 1989; Areas, 1992). It is probably a result of protein denaturation and inactivation of enzyme inhibitors present in raw plant foods, which might expose new sites for enzyme attack (Colonna et al., 1989). All processing variables have different effects in protein digestibility.An advantage of extrusion cooking is the destruction of antinutritional factors, especially trypsin inhibitors, haemagglutinins, tannins and phytates, all of which inhibit protein digestibility (Bookwalter et al., 1971; Lorenz and Jansen, 1980; Armour et al., 1998; Alonso et al., 1998, Alonso et al., 2000). The values for fats and ash followed the same pattern indicating similar degradation as result of extrusion process might likely result from the decrease in other nutrient compositions such as proteins and fat since the values were calculated based on percent. The value of the carbohydrate increases to make up for the reduction in the other nutrients. Other researchers reported similar findings (Filli et al., 2012). Starch polymers are very good at forming structures of extruded products. This is created by forming a melt fluid from biopolymers and blowing bubbles of water vapour into the fluid to form a foam. The film of biopolymers must flow easily in the bubble walls to allow the bubbles to expand as the superheated water is released very quickly at atmospheric pressure. Well-expanded cellular structures can be made from any of the separated starches available from materials such as wheat, maize, rice sorghum or potato (Riaz, 2000). 
Jiddere G. \& Filli K. : J. Food Sci. Technol. Nepal, Vol. 9 (55-65), 2016

Table 3. Proximate composition of Extruded and Unextruded blends (\%)

\begin{tabular}{lllllll}
\hline S/N & Sample & Carbohydrate & Protein & Fat & Ash & Water \\
\hline 1 & M0T0 & $71.0 \pm 03 \mathrm{~g}$ & $12.5 \pm 08 \mathrm{a}$ & $5.0 \pm 08 \mathrm{a}$ & $2.6 \pm 08 \mathrm{~b}$ & $8.5 \pm 06 \mathrm{a}$ \\
2 & MIT1 & $79.6 \pm 06 \mathrm{~d}$ & $11.3 \pm 03 \mathrm{de}$ & $2.1 \pm 04 \mathrm{~b}$ & $1.5 \pm 03 \mathrm{e}$ & $5.2 \pm 03 \mathrm{e}$ \\
3 & M2T1 & $79.7 \pm 06 \mathrm{~d}$ & $11.6 \pm 01 \mathrm{bc}$ & $1.2 \pm 02 \mathrm{f}$ & $1.5 \pm 04 \mathrm{e}$ & $5.8 \pm 02 \mathrm{~b}$ \\
4 & M3T1 & $79.8 \pm 03 \mathrm{~d}$ & $11.7 \pm 05 \mathrm{~b}$ & $1.3 \pm 05 \mathrm{e}$ & $1.9 \pm 07 \mathrm{~d}$ & $5.1 \pm 01 \mathrm{f}$ \\
5 & MIT2 & $79.0 \pm 04 \mathrm{ef}$ & $11.1 \pm 06 \mathrm{f}$ & $1.5 \pm 07 \mathrm{~d}$ & $2.6 \pm 03 \mathrm{bc}$ & $5.5 \pm 02 \mathrm{c}$ \\
6 & M2T2 & $79.2 \pm 00 \mathrm{e}$ & $11.4 \pm 04 \mathrm{~cd}$ & $0.7 \pm 01 \mathrm{~h}$ & $2.7 \pm 03 \mathrm{~b}$ & $5.8 \pm 03 \mathrm{~b}$ \\
7 & M3T2 & $78.9 \pm 04 \mathrm{f}$ & $11.5 \pm 03 \mathrm{~b}$ & $1.1 \pm 01 \mathrm{~g}$ & $2.9 \pm 05 \mathrm{a}$ & $5.4 \pm 03 \mathrm{~d}$ \\
8 & M1T3 & $81.9 \pm 06 \mathrm{a}$ & $11.0 \pm 07 \mathrm{f}$ & $1.0 \pm 04 \mathrm{~g}$ & $1.5 \pm 01 \mathrm{e}$ & $4.3 \pm 04 \mathrm{~g}$ \\
9 & M2T3 & $80.3 \pm 07 \mathrm{~b}$ & $11.0 \pm 06 \mathrm{f}$ & $1.2 \pm 03 \mathrm{f}$ & $1.6 \pm 03 \mathrm{e}$ & $5.3 \pm 03 \mathrm{de}$ \\
10 & M3T3 & $80.1 \pm 05 \mathrm{c}$ & $11.7 \pm 03 \mathrm{~b}$ & $1.8 \pm 03 \mathrm{c}$ & $2.4 \pm 06 \mathrm{c}$ & $3.8 \pm 04 \mathrm{~h}$ \\
11 & MEAN & 79.03 & 11.55 & 1.70 & 2.13 & 5.54 \\
\hline
\end{tabular}

$\mathrm{M} 1=20 \%$ Moisture, $\mathrm{M} 2=25 \%$ Moisture, $\mathrm{M} 3=30 \%$ Moisture $1=100{ }^{\circ} \mathrm{C}, \mathrm{T} 2=120{ }^{\circ} \mathrm{C}, \mathrm{T} 3=130{ }^{\circ} \mathrm{C}, \mathrm{M} 0 \mathrm{~T} 0=\mathrm{Unextruded}$ blends.

The protein content varied from 11.07 to $11.75 \%$. The result indicated a decrease in protein content with increase in temperature (from $100^{\circ} \mathrm{C}$ to $130^{\circ} \mathrm{C}$ ), while an increase in the value of the protein was observed with increase feed moisture (20 to $30 \%$ ). Although extrusion increases the digestibility of proteins, several researchers have reported decreased protein content of extruded foods products. This might be as a result of the interaction between proteins and carbohydrates, lipids and other chemical products at higher temperatures, of significance is the maillard reaction (Mary et al., 2012).

Filli et al., (2012) reported that the FAO/WHO/UNU (1985) recommended minimum protein for supplementary mixtures to be $15.7 \%$. The result of the extruded products fall short of this figure but most foods intended either for breakfast or eaten as snacks are usually co-consumed with other foods. These may complement the protein. The process conditions used in the extrusion cooking -high barrel temperatures and low feed moistures are known to favour the maillard reaction. In the extrusion cooking of a cereal mixture, the loss of available lysine range from 32 to $80 \%$. But at higher feed moistures, there is a reduction in the depletion of the protein because water is a by-product of maillard reaction. Its accumulation in the blend will negate the formation of the reaction (Singh et al., 2007). This agrees with the findings in this work. Digestibility is considered as the quality determinant of proteins in Adults. The digestibility study was not carried out for this work, however Filli et al., (2012) reported that protein digestibility value of extrudates were higher than unextruded products. The possible cause might be because of denaturation of proteins and inactivation of antinutritional factors that impair digestion such as trypsin inhibitors, heamagglutinin, tannins and phytates which prohibit protein digestibility.
The fat content of the extrudate ranged from 1.013 to $2.18 \%$. It decreased with increase in temperature. Lipid complexes within amylose can be formed during many food processes, including extrusion. The type of starch and lipid present in a food influences the extent to which complexes are formed, with monoglycerides and free fatty acids more likely to form complexes than triglycerides when added to high amylose starch (Singh et al., 2007). Mary et al., (2012) reported that low feed moisture $(19 \%)$ and low barrel temperature $\left(110-140^{\circ} \mathrm{C}\right)$ resulted in the largest amount of complex formation between stearic acid and normal cornstarch with $25 \%$ amylose.Lipid is released from cells owing to the high temperature and physical disruption of plant cell walls. At the same time, small lipid levels $(<5 \%)$ facilitate steady extrusion and improve the texture. A decrease in extractable fat after extrusion cooking has been found with an average of $40 \%$ of the original recovered in extruded maize, by using different solvents (Nierle et al., 1980). Some lipid might be lost at the die as free oil, but this situation only occurs with high-fat materials, such as whole soy. Another explanation for the lower lipid level is the formation of complexes with amylose or protein (Camire, 2000a). When extrudates are digested with acid or amylase and then extracted with solvent, lipid recovery is higher. Although only $50 \%$ of the extractable lipids in extruded whole wheat were recovered, acid hydrolysis indicated that total fat was not significantly changed owing to extrusion (Wang and Klopfenstein, 1993). This agrees with the findings of this work as fat content decreased from $5.0 \%$ in unextruded blend to as low as $0.7 \%$ in extruded M2T2. High viscosity and longer residence time may also favour complex formation. In general, food lipid content appears to be lower after extrusion. Some lipids may be lost at the die as free oil, but this situation only occurs with high-fat materials such as whole soy. When extrudates are digested with acids or amylase, then extracted with solvent, 
lipid recovery is higher. Although only half of the ether extractable lipids in extruded whole wheat was recovered, acid hydrolysis indicated that total fat was not significantly changed due to extrusion (Mary et al., 2012).

The reduction in oil content as a result of extrusion process increased product stability by reducing lipid rancidity. Extrusion denatures enzymes that can promote oxidation, and lipids held within starch are less susceptible to oxidation. Compounds produced by maillard reactions can also act as antioxidants. Lipid oxidation resulting from the use of high temperatures may impact negatively on the sensory and nutritional attribute of foods. It probably does not take place during extrusion owing to the very short residence time (Singh et al., 2007). Table 3 contains the result for the Ash content of the various extrudates. The values ranged from 1.58 to $2.95 \%$. The values were significantly different at $p \geq 0.01$. The result showed that increase in feed moisture increased the ash content while barrel temperature had no effect. Camire (2001) reported that minerals are stable during extrusion cooking and that any change in the value could result from the wear on the extruder parts such as screw and barrel. Extrusion cooking generally affects macromolecules. Smaller molecules be impacted upon by either the extrusion process itself or by changes in larger molecules which in turn affects other compounds present in the food (Singh et al., 2007). This agreed with the findings of Nicole et al., (2010).

The moisture content of the extruded blends is shown on Table 3. The values were between the ranges of 3.85 to $5.88 \%$. They were significantly different at $p \geq 0.01$. From the results obtained, it can be deduced that blends extruded at higher temperatures $\left(130^{\circ} \mathrm{C}\right)$ and higher feed moistures $(30 \%)$ tend to lose more moisture than those extruded at lower temperatures $\left(100^{\circ} \mathrm{C}\right)$ and lower feed moistures $(20 \%)$. This result agreed with the work Bryant et al., (2001). The low moisture content in all the extruded blends is an indicator for good storability.

\section{Functional properties of the extruded blends}

The water adsorption index (WAI) of the extrudates is shown on Table 4. The result showed the WAI varied from 570 to $660 \%$ with the unextruded sample showing least absorption. The results of WAI are significant for the extruded and unextruded samples at $\mathrm{p} \geq 0.01$. The sample M1T2 representing the samples extruded with $20 \%$ moisture content and $120^{\circ} \mathrm{C}$ indicating probable more starch modifications. The WAI measures the amount of water adsorbed by starch and can be used as an index of starch gelatinization, since native starch does not absorb water at room temperature (Filli et al., 2010). Hydration depends on the availability of hydrophilic groups which bind water molecules and on the gel forming capacity of macromolecules. The ability of food to absorb water and retain water plays a major role in the texture performance of foods. Water adsorption without food component dissolution results in swelling and will impart such characteristic as body, viscosity, adhesion and gelation (Filli et al., 2012).It was observed that the barrel temperature had the highest coefficient and was found to have the most significant effect on the WAI of the extrudate. The positive sign of its coefficient showed that WAI of the extrudates increased sharply with the increase in the values of barrel temperature. WAI decreased with increased feed moisture and decreased with decreasing barrel temperature. Filli et al., (2012) reported a decrease in WAI as a result of increased feed moisture. The negative correlation between increased in feed moisture may be attributed to decreased expansion of fura samples with increase in feed moisture which caused decreased water uptake as a result of fewer capillary units formed within the fura extrudates.

The result of Water Soluble Index (WSI) is given in Table 4. Significant difference exists between the samples ( $p$ $\geq 0.01$ ). The unextruded sample recorded more soluble index which is expected because of the products of malting process which are essentially reducing sugars. These sugars were evidently to have been lost during extrusion process by forming insoluble complexes, resulting in lower WSI values by the extrudates. Otherwise it is expected that the extruded samples are supposed to show increased values of WSI.However theWSI decreased as the WAI increased for the extruded samples. The water solubility index (WSI) describes the rate and extend to which the powdered material or particles dissolve in water. It depends mainly on the chemical composition of this powder and its physical state (Qing-Bo et al., 2005). This agrees with the work of several authors who reported increase in WSI as WAI decreased (Filli et al.,2011). It is often believed thatWSI can be used as an indicator of starch degradation of molecular compounds, which measures the degree of starch conversion during extrusion and the amount of soluble polysaccharides released from the starch compounds after extrusion (Kirby et al., 1988). Binoy et al., (1996) reported that high shear can cause fragmentation of products from both Starch and Proteins; these degradation products are small and are generally soluble in water. The water solubility of extruded full fat soy and sweet potato blend decreased as water absorption index increased. The changes in WAI and WSI may be interpreted on the basis of starch -water interactions that govern the solid phase structure of the processed starch (Zamre et al., 2012). 
Table 4: Functional properties of extruded and unextruded blends

\begin{tabular}{llllllll}
\hline S/N & Sample & WAI $(\%)$ & WSI $(\%)$ & EI & BD $\left(\mathrm{g} / \mathrm{cm}^{3}\right)$ & EQWSV & WETTABILITY(seconds) \\
\hline 1 & M0T0 & $200 \pm 1 \mathrm{~h}$ & $8.4 \pm 02 \mathrm{a}$ & $0.00 \mathrm{~g}$ & $0.7 \pm 04 \mathrm{a}$ & $1.7 \pm 02 \mathrm{f}$ & $37.3 \pm 05 \mathrm{a}$ \\
2 & M1T1 & $625 \pm 2 \mathrm{c}$ & $3.2 \pm 03 \mathrm{f}$ & $3.8 \pm 80 \mathrm{a}$ & $0.3 \pm 01 \mathrm{~h}$ & $3.3 \pm 03 \mathrm{~d}$ & $17.3 \pm 04 \mathrm{f}$ \\
3 & M2T1 & $600 \pm 1 \mathrm{e}$ & $3.8 \pm 04 \mathrm{e}$ & $3.6 \pm 60 \mathrm{~b}$ & $0.3 \pm 02 \mathrm{e}$ & $3.6 \pm 05 \mathrm{~d}$ & $18.5 \pm 03 \mathrm{e}$ \\
4 & M3T1 & $550 \pm 1 \mathrm{~g}$ & $4.5 \pm 03 \mathrm{c}$ & $2.3 \pm 56 \mathrm{e}$ & $0.5 \pm 04 \mathrm{~d}$ & $3.3 \pm 06 \mathrm{~d}$ & $25.1 \pm 02 \mathrm{~d}$ \\
5 & M1T2 & $665 \pm 2 \mathrm{a}$ & $2.2 \pm 03 \mathrm{~h}$ & $3.3 \pm 70 \mathrm{c}$ & $0.2 \pm 06 \mathrm{i}$ & $4.5 \pm 04 \mathrm{c}$ & $15.2 \pm 06 \mathrm{~h}$ \\
6 & M2T2 & $610 \pm 2 \mathrm{~d}$ & $2.7 \pm 04 \mathrm{~g}$ & $3.2 \pm 20 \mathrm{~d}$ & $0.3 \pm 03 \mathrm{f}$ & $5.1 \pm 01 \mathrm{~b}$ & $16.5 \pm 04 \mathrm{~g}$ \\
7 & M3T2 & $600 \pm 2 \mathrm{e}$ & $3.0 \pm 06 \mathrm{Fg}$ & $1.9 \pm 03 \mathrm{f}$ & $0.5 \pm .03 \mathrm{c}$ & $2.7 \pm 06 \mathrm{e}$ & $29.1 \pm 01 \mathrm{c}$ \\
8 & M1T3 & $630 \pm 1 \mathrm{~b}$ & $3.9 \pm 04 \mathrm{e}$ & $3.5 \pm 76 \mathrm{~b}$ & $0.2 \pm 02 \mathrm{i}$ & $4.5 \pm 03 \mathrm{c}$ & $13.7 \pm 05 \mathrm{j}$ \\
9 & M2T3 & $600 \pm 1 \mathrm{e}$ & $4.2 \pm 06 \mathrm{~d}$ & $3.1 \pm 40 \mathrm{~d}$ & $0.3 \pm 02 \mathrm{~g}$ & $6.1 \pm 04 \mathrm{a}$ & $14.3 \pm 03 \mathrm{i}$ \\
10 & M3T3 & $570 \pm 1 \mathrm{f}$ & $6.0 \pm 02 \mathrm{~b}$ & $1.8 \pm 83 \mathrm{f}$ & $0.6 \pm 07 \mathrm{~b}$ & $5.2 \pm 05 \mathrm{~b}$ & $33.4 \pm 04 \mathrm{~b}$ \\
11 & MEAN & 565.5 & 4.26 & 2.74 & 0.46 & 5.63 & 22.05 \\
\hline
\end{tabular}

$\mathrm{M} 1=20 \%$ Moisture, $\mathrm{M} 2=25 \%$ Moisture, $\mathrm{M} 3=30 \%$ Moisture. $\mathrm{T} 1=100{ }^{\circ} \mathrm{C}, \mathrm{T} 2=120{ }^{\circ} \mathrm{C}, \mathrm{T} 3=130{ }^{\circ} \mathrm{C}, \mathrm{M} 0 \mathrm{~T} 0=$ unextruded blend.

$\mathbf{W A I}=$ Water absorption index, $\mathbf{W S I}=$ Water solubility index, $\mathbf{E I}=$ Expansion index, $\mathbf{B D}=\mathrm{Bulk}$ density, $\mathbf{E Q W S V}=\mathrm{Qffect}$ of quantity of water on swell volume.

Table 4 showed the result of the Expansion Index (EI) extruded blends. The result varied from $1.88 \%$ to $3.88 \%$. Statistical analysis of the result indicates significant difference between all samples ( $p \geq 0.01)$. The temperature increase from $100^{\circ} \mathrm{C}$ to $130^{\circ} \mathrm{C}$ favoured the increase in expansion index especially at low feed moisture due to increase in the viscosity of the melt. When foods emerge from the extruder die, the pressure differentia between the extruder barrel and the atmospheric pressure results in the expansion of the exiting product. The expansion ratio could be sectional as well as longitudinal. These expansion indices are brought about as a result of high barrel temperature and low feed moisture. The average polymer size found in most natural starches is far too large for the optimum expansion. The most abundant polymer amylopectin has a molecular weight of up to $10^{8} \mathrm{D}$, which gives poor flow properties in gas cell walls and low expansion (1-2 ml/g). However, the use of high levels of mechanical shear during extrusion cooking can reduce the average molecular weight of amylopectin to $10^{6} \mathrm{D}$. The smaller molecules allow much more flow in bubble cells walls and cause an increase in expansion from 1 to $25 \mathrm{ml} / \mathrm{g}$. The natural starch from amylomaize, which contains a large proportion of the smaller starch polymer amylose $\left(2-10^{5} \mathrm{D}\right)$, gives the largest expansion of the native starches. Structure forming polymers must have a minimum molecular weight sufficient to give enough fluid viscosity to prevent or control the shrinkage of an extrudate after it has reached its maximum expansion and ruptured the gas cells. If the extrudate is too viscous at this point there will be rapid shrinkage and loss of apparent expansion in extrudates. This occurs when starch polymers are reduced in size to form maltodextrins. At this stage their viscosity is too low at the moisture levels used in extrusion either to induce rupture or stabilize the cell walls against elastic recoil effects. Their extrudates will collapse after expansion due to low internal pressure in the unbroken bubbles or low viscosity to give 62 little apparent expansion on cooling. Therefore, they are not classified as structure-forming materials (Leszek and Dick 2000).

Bulk densities of the various extrudates are reported on Table 4. The result of the values ranged from $0.11 \mathrm{~g} / \mathrm{cm}^{3}$ to $6.19 \mathrm{~g} / \mathrm{cm}^{3}$. The results were significant at $\mathrm{p} \geq 0.01$. During extrusion bulk densities of extrudates were affected by both feed moisture contents and barrel temperature. The increased barrel temperature favoured the reduction in bulk density while feed moisture increase was responsible for bulk density increase. Mostly it is seen that as expansion ratio increase the bulk density decreased under similar extrusion processing conditions. Bulk density and expansion ratio are also associated to starch gelatinization. An increase in gelatinization results in increase of expansion ratio and significant decrease in bulk density (Mary et al., 2012). There is a strong proof in the literature that raw materials having high-fibre, high-protein contents added to starchbased extruded products, increase the bulk density of extrudates.

The Effect of quantity of water on swell volume (EQWSV) of products gives an indication of the quantity of water that is required for full swelling (Filli et al., 2012). The results are shown on Table 4 and they were significantly different $(p \geq 0.01)$. The value ranged from 1.7 to 6.1 . Feed moisture had negative effect on EQWSV this is because as the moisture increased, the expansion index also decreased which reduces the porosity which are necessary for the absorption and subsequent swelling of the extrudate. Process temperature favours increase in the values of EQWSV. This might likely be as a result of the positive relationship between expansion index and temperature. The wettability of a food product describes the ability of the powdered particles to absorb water on its surface, thus 
initiating reconstitution. The wettability of the extruded samples is given on Table 4. The values ranged from 13.7 to 33.4 Seconds. The values are significantly different at $p \geq$ 0.01 . The values were affected by both temperature and feed moisture. The later has a negative correlation with blends; as feed moisture increased, the wettability decreased. But temperature has a positive relationship with the values. This property largely depends on particle size and the existing porosity. The extrudates with high expansion index have lesser wettability period when compared with those with little expansion (Filli et al., 2011).

\section{Extrudates photographic responses}

The visual effects of the extrusion variables (feed moisture content and barrel temperature) can be seen as shown in plates I - IX. The effect of the independent variables on the expansion index and colour of the extrudates is visual and clear. The photographic response on plates III, VI and IX had the least expansion index, they also show more wrinkles as the barrel temperature increased (from $100^{\circ} \mathrm{C}$ to $130^{\circ} \mathrm{C}$ ) and their colours are darker, this is as a result of the increased feed moisture $(30 \%)$ which reduced the expansion index resulting in a more concentrated components resulting in darker colours, this finding agree with the report by Filli et al., (2012).

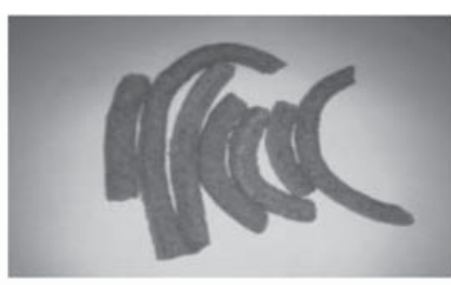

Plate I: M1T1

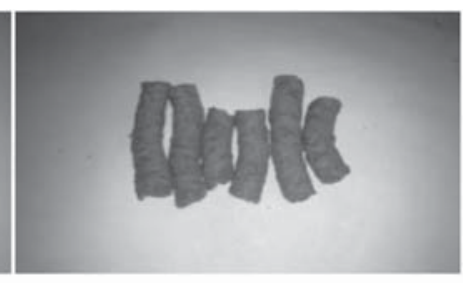

Plate II: M2T1

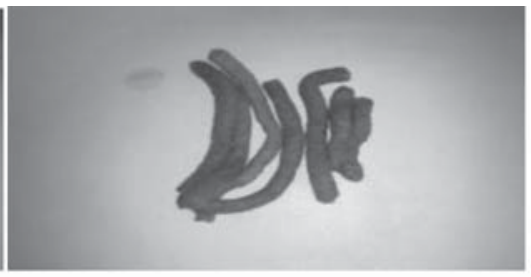

Plate III: M3T1

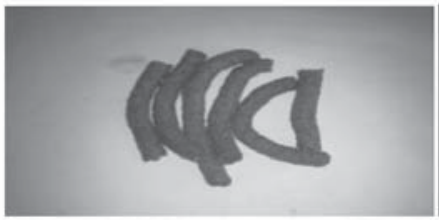

Plate IV: M1T2
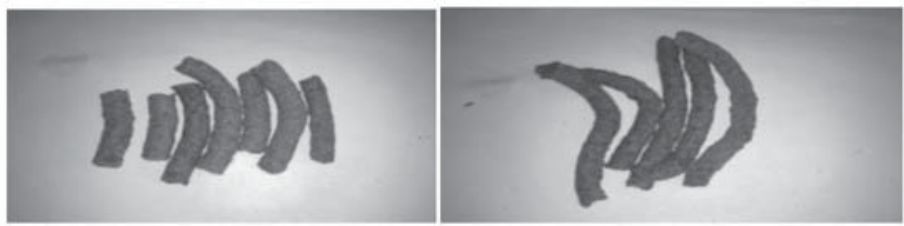

Plate VIII: M2T3

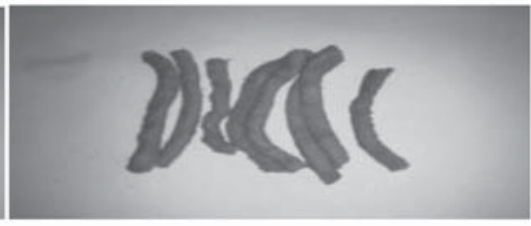

Plate VI: M3T2

\section{Plate VII: M1T3}

Plate V: M2T2

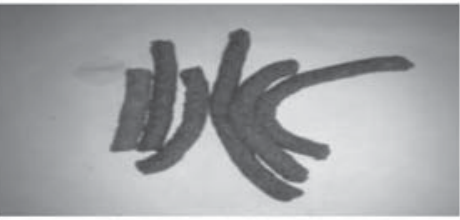

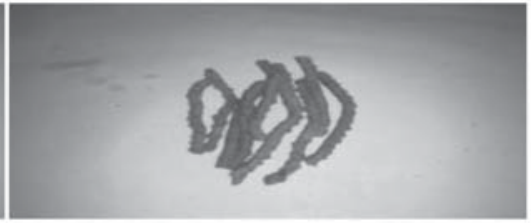

Plate IX: M3T3

Plates: I - IX, M1 =20\% Moisture; M2=25\% Moisture; M3=30\% Moisture; T1 $=100{ }^{\circ} \mathrm{C} ; \mathrm{T} 2=120{ }^{\circ} \mathrm{C} ; \mathrm{T} 3=130{ }^{\circ} \mathrm{C}$

\section{Conclusion}

Extrusion cooking permits the utilization and co-processing of various types of by-products. Beneficial nutritional effects range from increased protein and starch digestibility for enhanced nutritious food to the preparation of lowcost, protein-enriched or nutritionally balanced foods and feeds. Cereals (sorghum, maize, millets, rice) and tubers provide the bulk of calories in the form of starch based foods consumed by most people in Africa, particularly those living in thesub Saharan region. Thus studies of extrusion effects on cereals for food security purposes are significant.
From the results obtained above, it can be concluded that barrel temperature had a positive effect on the water absorption index (WAI), wettability and effect of quantity of water on the swell volume(EQWSV) indicating such product can be prepared with ease before consumption. The bulk density, water solubility index (WSI) on the hand decreased with increase in temperature. Feed moisture increase had a negative effect on bulk density, WAI, wettability and EQWSV but positive responses were recorded for protein retentionand WSI. FAO/WHO/UNU (1985) minimum protein recommended for supplementary mixtures as reported by Filli et al., (2012) should be $15.7 \%$ The result of the protein content extruded products 
fall short of this figure but most foods intended either for breakfast or eaten as snacks are hardly eaten alone. The research was based on scientific procedures which can be interpreted for applications with respect to its originality and strategically for an industry-driven programmewith the focus of yielding results that can be translated directly into real products for mitigating food security problems in Sub Saharan Africa. Malnutrition is prevalent and serious problem in Africaespecially in northern Nigeria wheremost of the population are ravaged and displaced by the violent activities of the terrorists Boko Haram against the citizens.

\section{References}

AOAC (1984). Official Methods of Analysis $14^{\text {th }}$ ed. Association of official analytical chemist, Washington D.C.

Alonso R., Orue E. and Marzo F. (1998). Effects of extrusion and conventional processing methods on protein and antinutritionalfactor contents in pea seeds. Food Chemistry, 63: 505-512.

Alonso R., Orue E., Zabalza M. J., Grant G. and Marzo F. (2000). Effect of extrusion cooking on structure and functional properties of pea and kindey bean proteins. Journal of the Science of Food and Agriculture, 80: 397403.

Areas J. A. G. (1992). Extrusion of proteins. Critical Reviews in Food Science and Nutrition, 32:365-392.

Armour J. C., Perera R. L. C., Buchan W. C. and Grant G. (1998). Protease inhibitors and lectins in soya beans and effect of aqueous heat-treatment. J. of the Sci. of Food and Agriculture, 78: 225-231.

Beaufrand M. J., De la Gueviviere J. F., Monnier C. and Poullain B. (1978). Influence du procede de cussionextrusionsur la disponibilitedes proteines. Annales De La Nutrition et de L Alimentation, 32, 353-364.

Binoy K. G., Aron J. O. and Gour S. C. (1996). Reverse screw elements and feed composition effects during twinscrew extrusion of rice flour and fish muscle blends. $J$. Food Sci.61 (3): 590-595.

Bookwalter G.N., Mustakas G. C., Kwolek W. F., Mcghee J. E. and Albrecht W. J. (1971). Full-fat soy flour extrusion cooked-properties and food uses. Journal of Food Science, 36: 5-9.

Bryant R. J., Kadan R. S., Champagne E. T., Vinyard B. T. and Boykin D. (2001). Functional and Digestive Characteristics of Extruded Rice Flour.Cereal chemistry 78 (2): 131-137.
Camire M. F. (2001). Extrusion and nutritional quality In R. Guy (2001) (ed) Extrusion cooking technologies and applications. Wood head press, London. UK.

Camire M. E. (2000a). Chemical and nutritional changes in food during extrusion. In: Extruders in Food Applications (edited by M.N.Riaz). Pp. 127-147. Boca Raton, FL: CRC Press.

Chessari C. J and Sellahewa J. N (2012). Effective process control In: extrusion cooking technology and applications. Edited by: Robin Guy.Woodhead publishing limited Cambridge. England.

Colonna P., Tayeb J. and Mercier C. (1989). Extrusion cooking of starch and starchy products. In: Extrusion Cooking (edited by C. Mercier, P. Linko \& J.M. Harper). Pp. 247-319. St. Paul, MN: American Association of Cereal Chemists, Inc.

De Pilli T., Severini C., Carbone B. F., Guiliani R. and Derossi A. (2004). Improving fatty extrudate structure with amylase and protease.J. Food biochemistry. 21(2):387-403.

Egan H., Kirk R. and Suwyer R. (1981). Pearsons Chemical analyses of foods. $2^{\text {nd }}$ edition. Longman group London

FAO/WHO/UNU (1985). Energy and protein requirements. Tech. Rep. Series 724, Expert Consultation. Geneva: World Health Organisation.

Filli K. B., Nkama I., Abubakar U. M. and Jideani V. A. (2010). Influence of extrusion variables on some functional properties of extruded millet-soybean for the manufacture of Fura: A Nigerian traditional food. Africa Journal of food science vol. 4(6):342-351

Filli K. B., Nkama I., Jideani V. A. and Abubakar U. M. (2011). Application of response surface methodology for the study of composition of extruded millet-cowpea mixtures for the manufacture of fura: a nigerian food. African journal of food science and technology 5(16).

Filli K. B., Nkama I., Jideani V. A. and Ibok U. I. (2012). Effects of process variables on the Hydration properties and acceptability of extruded millet-soybean blends for fura manufacture: A Nigerian Traditional Food. (Accepted for Publication in British food journal)

Hakansson B., Jagerstad M., Oste R., Akesson B. and Jonssson L. (1987). The effects of various thermal processes on protein quality,vitamins and selenium content in wholegrain wheat and white flour. Journal of Cereal Science, 6: 269-282. 
Iwuono J. C. and Ojukwu M. (2012). Effects of experimental variables on the malting quality of nigerian yellow maize (zea mays) ferz 27 variety. African journal of food science and technology. 3(10):252-259.

Kirby A. R., Oleffe A. L., Parker R. and Smith A. C. (1988). An experimental study of screw configuration effects in the twin-screw extrusion-cooking of maize grit. J. Food Engineering 8,247-272

Leszek M. and Dick J. C. (2001). Extrusion-Cooking Techniques: Applications, Theory and Sustainability. Edited by LeszekMoscicki. WILEY-VCH Verlag GmbH \& Co. KGaA, Weinheim Pp 1-24.

Lorenz K. and Jansen G. R. (1980). Nutrient stability of full-fat soy flour and corn-soy blends produced by low-cost extrusion.Cereal Foods World, 25: 161-172.

Nierle W., Elbaya A.W., Seiler K., Fretzdorff B. and Wolff J. (1980).Veranderungen dergetreideinhaltsstoffewahrendderextrusionmiteinemdoppelschneckenextruder. GetreideMehlBrot, 34: 73-76.

Mary E. C. (2012). Chemical and nutritional changes in food during extrusion. DOI: $p d f / 10.1080$.

Mosha A. C. and Wilbald S. M. C. (1997). High-nutrient density creaming foods from germinated cereals. In: Improving young child feeding in eastern and southern Africa. Household-level food technology. Proceedings of a workshop held in Nairobi, Kenya.

Nicole M., Fei H. Y. and Claver I. P. (2010). Charactreization of ready-to-eat composite porridge flours made by soymaize-sorghum-wheat extrusion cooking process. Pakistan J. of Nutrition. 9 (2):171-178.

Quang D. T., Wouter H. H. and Antonius F. B. V. (2008). Effects of Extrusion processing on nutrients in dry pet food. Journal of the science of food and Agriculture. 88:14871493.

Qing-Bo D., Ainsworth P., Tuker G. and Marson H. (2005). The effect of extrusion conditions on the physicochemical properties and sensory characteristics of rice-based expanded snacks, Journal of food engineering 66(1):284289.

Razzaq M. R., Anjum F. M., Khan M. I., Khan M. R., Nadeem M., Javed M. S. and Sajid M.W. (2012). Effect of temperature, screw speed and moisture variations on extrusion cooking behavior of Maize (Zea mays.L). Pak. J. Food Sci., 22: 1 12-22
Riaz M. N. (2000). Extruders in food applications. CRC press Taylor and Francis group. 6000 Broken sand parkway, NW, Suit 2000 Boca Raton.

Singh S., Shirani G. and Lara W. (2007) . Nutritional aspects of food extrusion: a review. International Journal of Food Science and Technology 2007, 42: 916-929.

SPSS (1998). Statistical package for the social sciences for windows Illinois, USA: SPSS

Srihara P. and Alexander J. C. (1984). Effect of heat treatment on nutritive quality of plant protein blends. Canadian Institute of Food Science and Technology Journal, 17: 237-241.

Wang W. M. and Klopfenstein C. F. (1993). Effects of twinscrew extrusion on the nutritional quality of wheat, barley, oats.Cereal Chemistry, 70: 712-725.

Zamre M. B., Jadhav M. V. and Uday S. A. (2012). Process Optimization and Characterization of Sorghum Based Extruded Product. Journal of Food Science and Engineering 2:367-375. 